Short communication

\title{
Gramineous and non-gramineous weed species as alternative hosts of Fusarium graminearum, causal agent of Fusarium head blight of wheat, in Argentina
}

\author{
C.A. Mourelos ${ }^{\text {a, }}{ }^{\text {, }}$ I. Malbrán ${ }^{\text {a }}$, P.A. Balatti ${ }^{\text {a }}$, P.D. Ghiringhelli ${ }^{\text {b }}$, G.A. Lori ${ }^{\text {a }}$ \\ ${ }^{a}$ Centro de Investigaciones de Fitopatología (CIDEFI-UNLP-CIC), Facultad de Ciencias Agrarias y Forestales, Universidad Nacional de La Plata, 60 y 119, CC \\ 31, 1900 La Plata, Buenos Aires, Argentina \\ ${ }^{\mathrm{b}}$ Laboratorio de Ingeniería Genética, Biología Celular y Molecular (LIGBCM), Departamento de Ciencia y Tecnología, Universidad Nacional de Quilmes, \\ Roque Sáenz Peña 352, 1876 Bernal, Buenos Aires, Argentina
}

\section{A R T I C L E I N F O}

\section{Article history:}

Received 4 April 2014

Received in revised form

21 July 2014

Accepted 22 July 2014

Available online

\section{Keywords:}

Inflorescences of weeds

FHB epidemiology

Cultural practices

Mycotoxins

Trichothecene chemotypes

FHB inoculum source

\begin{abstract}
A B S T R A C T
Weeds and wild plants around and within crops could serve as alternative hosts of fungal pathogens. In this work we describe the isolation of Fusarium graminearum, the main causal agent of Fusarium head blight (FHB) in Argentina from the inflorescences of healthy weed plants belonging to sixty seven gramineous and non-gramineous species, which showed no symptoms of Fusarium infection, sampled throughout a year. Fifty four of the weed species considered, belonging to 19 botanical families, were first identified as alternative hosts of $F$. graminearum in the present work. Furthermore, the trichothecene chemotype of a group of isolates was analysed and strains belonging to 15-acetyldeoxynivalenol, 3acetyldeoxynivalenol and nivalenol chemotypes were found. The information provided could prove valuable to study further the epidemiological role of weeds in FHB epidemics, which might help to improve management of the disease in wheat growing areas.
\end{abstract}

() 2014 Elsevier Ltd. All rights reserved.
Fusarium graminearum Schwabe [teleomorph Gibberella zeae (Schwein.)Petch], is the main causal agent of Fusarium head blight (FHB) of wheat and other small grains in Argentina (De Galich, 1997; Lori et al., 2003).

The pathogen damages yield and quality of the grain, mainly because of its frequent contamination with mycotoxins which constitute a risk for human and animal health (Kendrick, 1992). F. graminearum produces one of three sets of type-B trichothecene metabolites, nivalenol (NIV) and its acetylate derivative fusarenone $\mathrm{X}$ (FUS-X) (NIV chemotype), deoxynivalenol (DON) and 3acetyldeoxynivalenol (3-ADON chemotype) or DON and 15acetyldeoxynivalenol (15-ADON chemotype) (Ward et al., 2002). Different authors reported the prevalence of either DON or NIV chemotypes according to the geographic distribution of F. graminearum (Wang et al., 2011). In Argentina, although 15-ADON is the most common chemotype (Alvarez et al., 2009; Malbrán et al., 2014), the presence of NIV chemotype has also been

\footnotetext{
* Corresponding author. Tel.: +54 2214236758x423.

E-mail address: mouceci@yahoo.com.ar (C.A. Mourelos).
}

reported (Lori et al., 1992; Fernández Pinto et al., 2008; Sampietro et al., 2011; Reynoso et al., 2011).

Environmental conditions, mainly spike wetness duration and temperature, have been indicated as a key factor for the development of FHB epidemics (Moschini and Fortugno, 1996). Additionally, as FHB is a monocyclic disease (Landschoot et al., 2011), the quantity of primary inoculum available for infection could be of importance. However, under favourable climatic conditions, a rather small amount of inoculum might be enough to develop an epidemic (Dill-Macky and Jones, 2000; Miller et al., 1998).

Several structures produced by $F$. graminearum can act as inoculum for FHB, including macroconidia produced by saprophytic mycelia overwintering in the residues of several crops (Sutton, 1982; Bai and Shaner, 1994; Goswami and Kistler, 2004) as well as ascospores released by the pathogen from crop residues (Gilbert and Fernando, 2004; Dufault et al., 2006; Stein et al., 2009).

Recently, the host range of $F$. graminearum has expanded from cereal to non-cereal crops, including soybean (Glycine max L.) (Pioli et al., 2004; Broders et al., 2007). A host is defined as "a living organism harbouring a parasite" (Ainsworth, 1971) and under this definition are included both the economically important main hosts and potential alternative hosts. Several weed species have 
been identified as alternative hosts of $F$. graminearum and their possible role as inoculum sources for the development of FHB has been proposed (Jenkinson and Parry, 1994; Carmona et al., 1999; Inch and Gilbert, 2003; Pereyra and Dill-Macky, 2008; Landschoot et al., 2011; Postic et al., 2012; Tekle et al., 2012). Even though crop residues have been identified as the primary source of inoculum for the disease, the role weeds play in the epidemiology of FHB, especially non-gramineous species, remains an important aspect to be clarified and might lead to the development of management practices aimed at reducing their impact as inoculum sources. The objective of this work was to analyse the colonization of inflorescences of weeds belonging to different botanical families collected in the proximity of cropping areas by F. graminearum to establish their potential role as alternative hosts of the fungus.

Healthy, symptomless weed plants were randomly collected in the neighbourhood of soft wheat (Triticum aestivum L.) durum wheat (Triticum durum Desf.), barley (Hordeum vulgare L.), oat (Avena sativa L.), rye [Secale cereale (L.) M. Bieb.] and maize (Zea mays L.) crops. The assayed areas were located in the Estación Experimental Julio Hirschhorn of the Facultad de Ciencias Agrarias y Forestales, Universidad Nacional de La Plata, Provincia de Buenos Aires, Argentina ( $34^{\circ} 52^{\prime} \mathrm{S}$ y $57^{\circ} 58^{\prime} \mathrm{W}$ ). During a one year period, six sampling events were conducted (February, April, June, September and November 2010 and January 2011).

A total of 162 gramineous and non-gramineous weed samples were collected: 23 in February, 32 in April, 23 in June, 20 in September, 28 in November and 36 in January. Plants were taken to the laboratory, air dried, placed in paper envelopes and stored at $4{ }^{\circ} \mathrm{C}$ until they were processed. Weed species were identified according to their morphology by means of the identification keys by Cabrera and Zardini (1993).

Fusarium spp. isolates were obtained from whole weed inflorescences, which were dislodged from the plant. Larger inflorescences were cut into $0.5-2 \mathrm{~cm}$ pieces, each comprising at least one whole flower. Twelve pieces per plant were superficially disinfested by dipping in $70 \%$ ethanol for $1 \mathrm{~min}$ and in a $5 \% \mathrm{com}-$ mercial $\mathrm{NaClO}$ solution (55 $\mathrm{g}$ of $\mathrm{Cl} \mathrm{L}^{-1}$ ) for $1 \mathrm{~min}$, followed by rinsing in sterile distilled water for $5 \mathrm{~min}$. Surface-sterilized pieces of inflorescences were plated on two $9 \mathrm{~cm}$ Petri dishes (6 pieces per plate) containing potato dextrose agar medium (PDA) $2 \%(\mathrm{w} / \mathrm{v})$ supplemented with $250 \mathrm{mg} \mathrm{L}^{-1}$ of chloramphenicol and $600 \mathrm{mg} \mathrm{L}^{-1}$ of pentachloronitrobenzene (PCNB 75\% wettable powder). After 5-7 days of incubation at $25{ }^{\circ} \mathrm{C} \pm 2{ }^{\circ} \mathrm{C}$, the incidence of F. graminearum colonization (number of inflorescence pieces colonized over the total) was evaluated for each weed species and sampling event. Isolates of Fusarium spp. were transferred to PDA plates, incubated at $25^{\circ} \mathrm{C} \pm 2{ }^{\circ} \mathrm{C}$ for 7 days and identified based on the cultural features and morphology of spores and conidiogenous cells (Booth, 1971; Leslie and Summerell, 2006).

The identity of the isolates was confirmed by running a species specific PCR using primer pair Fg16NF (5'-ACA GAT GAC AAG ATT CAG GCA CA-3') and Fg16NR (5'-TTC TTT GAC ATC TGT TCA ACC CA$3^{\prime}$ ) developed by Nicholson et al. (1998) according to a modification of the procedure described by Malbrán et al. (2012).

Isolates identified as F. graminearum from 49 of the weed species considered were randomly chosen and their chemotype was analysed by means of the chemotype-specific multiplex PCR developed by Starkey et al. (2007). Primers 12NF ( $5^{\prime}$-TCT CCT CGT TGT ATC TGG-3'), 12-15F ( $5^{\prime}$-TAC AGC GGT CGC AAC TTC-3'), 12-3F (5'-CTT TGG CAA GCC CGT GCA-3') and 12CON (5'-CAT GAG CAT GGT GAT GTC- $\left.3^{\prime}\right)$, targeting the TRI12 gene, were used according to the procedure described by Malbrán et al. (2014).

Data taken as percentage were arcsine-transformed prior to analysis. The incidence of $F$. graminearum colonization of weed inflorescences in each of the sampling events was analysed by analysis of variance (ANOVA) and means were compared using Tukey's test $(P=0.05)$. The analyses were performed using Statistix v.8 sofware (Analytical Software, Tallahassee, USA).

Sixty seven species of weeds, belonging to 22 botanical families, were collected in 6 sampling events that were distributed during a year (Table 1). From the inflorescences of the 162 weed samples analysed, 1020 isolates of $F$. graminearum were obtained and identified by means of morphological and molecular features. Although other fusaria were collected from the inflorescences, F. graminearum was the prevalent species and was found colonizing every weed species tested. More than two thirds of the 67 weed species colonized by $F$. graminearum were non-gramineous.

None of the weed species analysed presented symptoms of Fusarium infection, in agreement with previous reports (Jenkinson and Parry, 1994; Inch and Gilbert, 2003). In this regard, an endophytic colonization by $F$. graminearum on alternative hosts has been suggested by Sieber et al. (1988). Moreover, Brown et al. (2010) demonstrated that during an asymptomatic stage of FHB development, F. graminearum hyphae can grow in the intercellular spaces within spikes feeding exclusively from the extracellular exudates.

The chemotype of $107 \mathrm{~F}$. graminearum isolates obtained from 49 weed species was determined. Ninety six isolates (89.7\%) belonged to the $15-A D O N$ chemotype, $2(1.9 \%)$ to the $3-A D O N$ and $9(8.4 \%)$ to the NIV chemotype (Table 1$)$. In Argentina, evidence suggests that the predominant trichothecene among $F$. graminearum populations is DON (Dalcero et al., 1997; Lori et al., 2003; Ramírez et al., 2006; Alvarez et al., 2009; Reynoso et al., 2011; Malbrán et al., 2014), even though NIV producers have been found (Lori et al., 1992; Fernández Pinto et al., 2008). In isolates obtained from wheat, 15-ADON producers prevailed (Alvarez et al., 2009; Reynoso et al., 2011; Malbrán et al., 2014) over those producing 3-ADON (Ramírez et al., 2006; Alvarez et al., 2009) and NIV (Lori et al., 1992; Fernández Pinto et al., 2008). In maize, on the other hand, an important presence of NIV producing isolates has been reported (Sampietro et al., 2011). The higher proportion of 15-ADON found in this work agrees with these reports. These results suggest that potential exists for the contamination of food and feeds with an important range of trichothecenes originated by the infection of economically important crops by $F$. graminearum isolates from weed species.

Thirteen weed species from 6 botanical families (Asteraceae, Chenopodiaceae, Convolvulaceae, Plantaginaceae, Poaceae and Polygonaceae) sampled in our work were previously cited as hosts of $F$. graminearum in Argentina (Carmona et al., 1999), Canada (Inch and Gilbert, 2003), Croatia (Postic et al., 2012), England (Jenkinson and Parry, 1994) and Uruguay (Pereyra and Dill-Macky, 2008). The presence of the fungus was reported on rhizomes and roots of plants of these weed species (Carmona et al., 1999; Postic et al., 2012). In this work, on the other hand, all the isolates were obtained from inflorescences. The colonization of weed inflorescences by $F$. graminearum could prove to be more relevant from an epidemiological point of view as FHB develops on the aerial organs of wheat. Fifty four weed species and 16 botanical families are reported as alternative hosts for the first time here (Table 1 ).

Weed species considered in our work had different growth habits and life cycles and as a consequence the species collected at each sampling event were different. Of the 67 weed species found, only Cynodon dactylon (L.) Pers., Cyperus eragrostis Lam., Picris echioides L., Raphanus sativus L., and Dactylis glomerata (L.) were present at all sampling events. Even though F. graminearum was found colonizing weed inflorescences throughout the year, the incidence of colonization in the different seasons was significantly different $(F=4.35 ; p<0.01)$. The highest incidences of colonization were found in the summer (69\% in February 2010) and spring seasons (58\% in November 2010 ) while the lower incidences corresponded to the autumn (45\% in April 2010) and winter seasons 
Table 1

List of families, species and habits of weeds sampled for isolation of Fusarium graminearum and chemotype of isolates identified by Polymerase Chain Reaction (PCR).

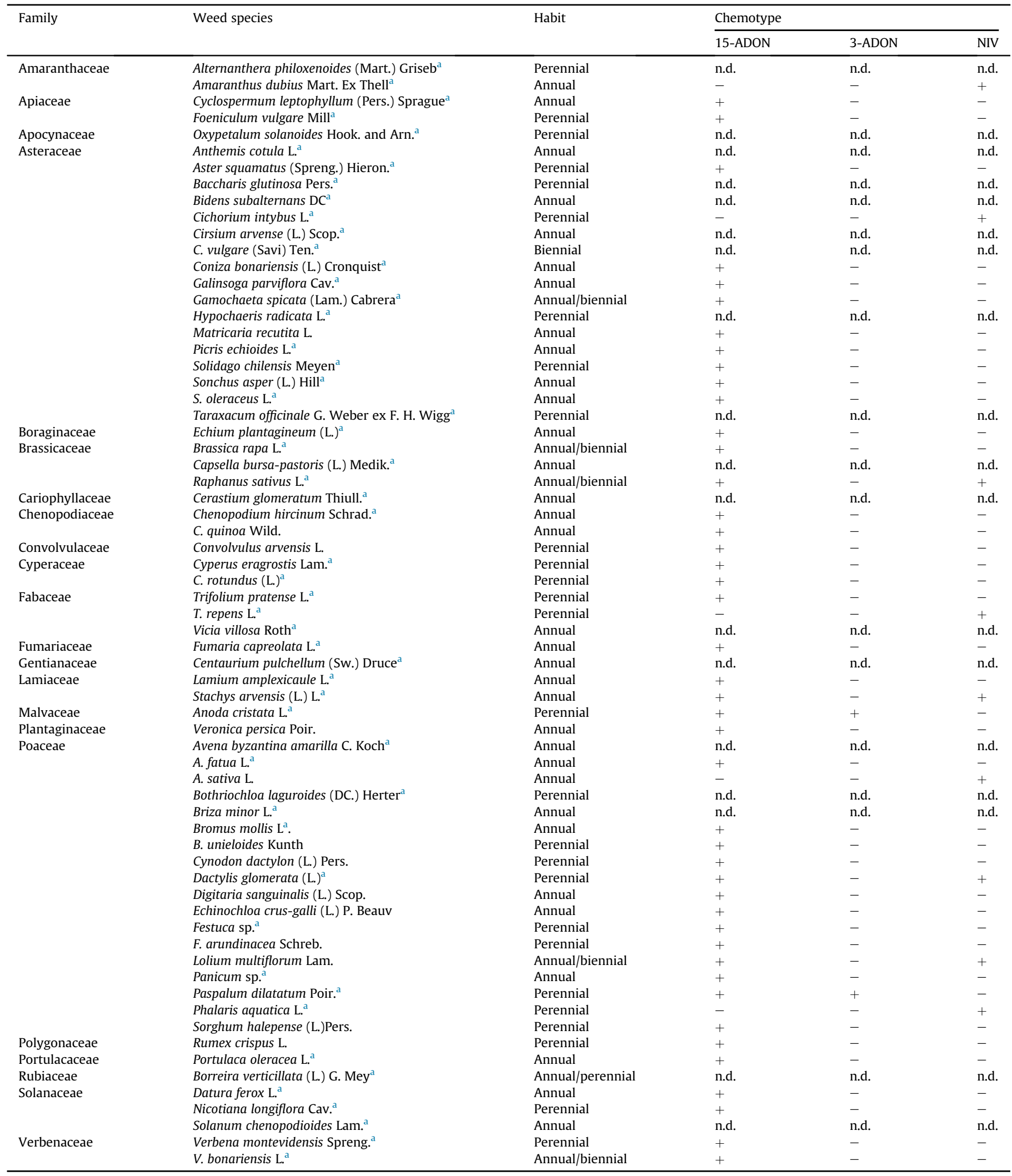

n.d.: Not determined.

a First report of $F$. graminearum isolation on this host. 
(46\% in June 2010). A similar trend was found when only the 5 species present in the 6 sampling events were analysed, even if the differences found were not significant $(F=2.11, P=0.0992)$.

In Argentina's Pampas Region, weather conditions favour the abundance and prevalence of weed plants surrounding and inside the cropping fields throughout the year. Such temperate weather conditions and the ample range of weed species hosting F. graminearum that had different growing habit might explain the ubiquitous presence of the pathogen.

Alternative hosts have been cited as important epidemiological bridges that allow for pathogen overseasoning, increasing or maintaining the amount of inoculum against the natural tendency for decrease in the absence of crops of the main host (Dinoor, 1974). Inch and Gilbert (2003) proposed that, due to the lack of perithecia of $G$. zeae, wild grasses would not contribute the ascospores that serve as initial inoculum for the development of FHB but could serve as reservoir for the pathogen in the fields when no susceptible hosts were present (Carmona et al., 1999; Inch and Gilbert, 2003). However, Pereyra and Dill-Macky (2008) reported the production of $G$. zeae perithecia on gramineous weed residues.

In Argentina, recent surveys indicate that 27 million hectares of crops (78.5\% of the total arable land in the country) are seeded under no tillage (Trigo et al., 2009; AAPRESID, 2012), which leaves a high amount of crop as well as weed residues on the soil surface. Under these conditions, alternative hosts of $F$. graminearum might not only act as a reservoir of the pathogen between two susceptible crops but also produce $G$. zeae perithecia on their residues that could in time serve as inoculum sources for initial FHB infection. Even if $G$. zeae produces fewer ascospores on weeds than on crop residues (Pereyra and Dill-Macky, 2008), its contribution could prove to be important under favourable weather conditions (Lori et al., 2009).

The information provided in this work could prove valuable to better understanding the epidemiology of $F$. graminearum and for the development of management practices aimed at reducing the amount of inoculum available for FHB epidemics. However, further research is necessary to accurately define the impact of weeds as alternative hosts. Future work should focus on the precise determination of the infection mechanism employed by the fungus in its interaction with weed plants as well as the type of inoculum provided by spontaneous species and its importance for the epidemiology of FHB. In this regard, work is being conducted to evaluate the pathogenicity of the $F$. graminearum strains recovered from weed inflorescences.

\section{Acknowledgements}

C.A. Mourelos and I. Malbrán are grant holders and P.D. Ghiringhelli is a member of the Consejo Nacional de Investigaciones Científicas y Técnicas (CONICET). P.A. Balatti and G.A. Lori are members of the Comisión de Investigaciones Científicas de la Provincia de Buenos Aires (CICBA). This study was supported by CICBA and project ANPCyT PICT-PAE 37046-77/07. The authors wish to thank J. Vera Bahima and N. Bayón for their kind support in the identification of the weed species.

\section{References}

AAPRESID, 2012. Evolución de la superficie en Siembra Directa en Argentina. Available at: http://www.aapresid.org.ar/wp-content/uploads/2013/02/ aapresid.evolucion_superficie_sd argentina.1977_a_2011.pdf (last accessed 17.07.14.)

Ainsworth, G.C., 1971. Ainsworth and Bisby's Dictionary of the Fungi, sixth ed Commonwealth Mycological Institute, Kew, Surrey, UK.

Alvarez, C.L., Azcarate, M.P., Pinto, V.F., 2009. Toxigenic potential of Fusarium graminearum sensu stricto isolates from wheat in Argentina. Int. J. Food Microbiol. 135, 131-135.
Bai, G.H., Shaner, G., 1994. Scab of wheat: prospects for control. Plant Dis. 78, $760-766$.

Booth, C., 1971. The genus Fusarium. Commonwealth Mycological Institute, Kew, Surrey, UK.

Broders, K.D., Lipps, P.E., Paul, P.A., Dorrance, A.E., 2007. Evaluation of Fusarium graminearum associated with corn and soybean seed and seedling disease in Ohio. Plant Dis. 91, 1155-1160.

Brown, N.A., Urban, M., Van de Meene, A.M.L., Hammond-Kosack, K.E., 2010. The infection biology of Fusarium graminearum: defining the pathways of spikelet to spikelet colonisation in wheat ears. Fungal Biol. 114, 555-571.

Cabrera, A.L., Zardini, E.M., 1993. Manual de la flora de los alrededores de Buenos Aires. ACME, Buenos Aires, Argentina.

Carmona, M.A., Pioli, R., Reis, E.M., 1999. Malezas hospedantes de hongos necrotroficos causantes de enfermedades en trigo y cebada cervecera en la región pampeana. [Survey of weed plants hosts of pathogenic necrotrophic fungi that cause diseases on wheat and barley in the Argentine Pampas Regions]. Rev. Fac. Agron. (B. Aires) 19, 105-110.

Dalcero, A., Torres, A.M., Etcheverry, M., Chulze, S.N., Varsavsky, E., 1997. Occurrence of deoxynivalenol and Fusarium graminearum in Argentinian wheat. Food Addit. Contam. 14, 11-14.

De Galich, M., 1997. Fusarium head blight in Argentina. In: Fusarium Head Scab: Global Status and Future Prospects. CIMMYT, Mexico, D.F.

Dill-Macky, R., Jones, R.K., 2000. The effect of previous crop residues and tillage on Fusarium head blight of wheat. Plant Dis. 84, 71-76.

Dinoor, A., 1974. Role of wild and cultivated plants in the epidemiology of plant diseases in Israel. Annu. Rev. Phytopathol. 12, 413-436.

Dufault, N.S., De Wolf, E.D., Lipps, P.E., Madden, L.V., 2006. Role of temperature and moisture in the production and maturation of Gibberella zeae perithecia. Plant Dis. 90, 637-644.

Fernández Pinto, V., Terminiello, L.A., Basilico, J.C., Ritieni, A., 2008. Natural occurrence of nivalenol and mycotoxigenic potential of Fusarium graminearum strains in wheat affected by head blight in Argentina. Braz. J. Microbiol. 39, 157-162.

Gilbert, J., Fernando, W.G.D., 2004. Epidemiology and biological control of Gibberella zeae/Fusarium graminearum. Can. J. Plant Pathol, 26, 464-472.

Goswami, R.S., Kistler, H.C., 2004. Heading for disaster: Fusarium graminearum on cereal crops. Mol. Plant Pathol. 5, 515-525.

Inch, S., Gilbert, J., 2003. The incidence of Fusarium species recovered from inflorescences of wild grasses in southern Manitoba. Can. J. Plant Pathol. 25, 379-383.

Jenkinson, P., Parry, D.W., 1994. Isolation of Fusarium species from common broadleaved weeds and their pathogenicity to winter wheat. Mycol. Res. 98, $776-780$.

Kendrick, B., 1992. Mycotoxins in food and feeds. In: The Fifth Kingdom. Focus Texts, Newburyport, Massachusetts, USA, pp. 316-331.

Landschoot, S., Audenaert, K., Waegeman, W., Pycke, B., Bekaert, B., De Baets, B. Haesaert, G., 2011. Connection between primary Fusarium inoculum on gramineous weeds, crop residues and soil samples and the final population on wheat ears in Flanders, Belgium. Crop Prot. 30, 1297-1305.

Leslie, J.F., Summerell, B.A., 2006. The Fusarium Laboratory Manual, first ed. Blackwell Publishing, Ames, Iowa, USA.

Lori, G.A., Sisterna, M.N., Haidukowski, M., Rizzo, I., 2003. Fusarium graminearum and deoxynivalenol contamination in the durum wheat area of Argentina. Microbiol. Res. 158, 29-35.

Lori, G.A., Sisterna, M.N., Sarandón, S.J., Rizzo, I., Chidichimo, H., 2009. Fusarium head blight in wheat: impact of tillage and other agronomic practices under natural infection. Crop Prot. 28, 495-502.

Lori, G.A., Carranza, M.R., Violante, A., Rizzo, I., Alippi, H.E., 1992. Fusarium spp en trigo, capacidad toxicogénica y quimiotaxonomía de las cepas aisladas en la Argentina. Agronomie 12, 459-467.

Malbrán, I., Mourelos, C.A., Girotti, J.R., Aulicino, M.B., Balatti, P.A., Lori, G.A., 2012. Aggressiveness variation of Fusarium graminearum isolates from Argentina following point inoculation of field grown wheat spikes. Crop Prot. 42, 234-243.

Malbrán, I., Mourelos, C.A., Girotti, J.R., Balatti, P.A., Lori, G.A., 2014. Toxigenic capacity and trichothecene production of Fusarium graminearum isolates from Argentina and its relationship with aggressiveness and fungal expansion in the wheat spike. Phytopathology 104, 357-364.

Miller, J.D., Culley, J., Fraser, K., Hubbard, S., Meloche, F., Ouellet, T., Seaman, W.L., Seifert, K.A., Turkington, K., Voldeng, H., 1998. Effect of tillage practice on fusarium head blight of wheat. Can. J. Plant Pathol. 20, 95-103.

Moschini, R.C., Fortugno, C., 1996. Predicting wheat head blight incidence using models based on meteorological factors in Pergamino, Argentina. Eur. J. Plant Pathol. 102, 211-218.

Nicholson, P., Simpson, D.R., Weston, G., Rezanoor, H.N., Lees, A.K., Parry, D.W., Joyce, D., 1998. Detection and quantification of Fusarium culmorum and Fusarium graminearum in cereals using PCR assays. Physiol. Mol. Plant Pathol. 53, $17-37$.

Pereyra, S.A., Dill-Macky, R., 2008. Colonization of the residues of diverse plant species by Gibberella zeae and their contribution to Fusarium head blight inoculum. Plant Dis. 92, 800-807.

Pioli, R.N., Mozzoni, L., Morandi, E.N., 2004. First report of pathogenic association between Fusarium graminearum and soybean. Plant Dis. 88, 220.

Postic, J., Cosic, J., Vrandecic, K., Jurkovic, D., Saleh, A.A., Leslie, J.F., 2012. Diversity of Fusarium species isolated from weeds and plant debris in Croatia. J. Phytopathol. 160, 76-81. 
Ramirez, M.L., Reynoso, M.M., Farnochi, M.C., Chulze, S., 2006. Vegetative compatibility and mycotoxin chemotypes among Fusarium graminearum (Gibberella zeae) isolates from wheat in Argentina. Eur. J. Plant Pathol. 115, 139-148.

Reynoso, M.M., Ramirez, M.L., Torres, A.M., Chulze, S.N., 2011. Trichothecene genotypes and chemotypes in Fusarium graminearum strains isolated from wheat in Argentina. Int. J. Food Microbiol. 145, 444-448.

Sampietro, D.A., Díaz, C.G., Gonzalez, V., Vattuone, M.A., Ploper, L.D., Catalan, C.A.N., Ward, T.J., 2011. Species diversity and toxigenic potential of Fusarium graminearum complex isolates from maize fields in northwest Argentina. Int. J. Food Microbiol. 145, 359-364.

Sieber, T., Riesen, T.K., Müller, E., Fried, P.M., 1988. Endophytic fungi in four winter wheat cultivars (Triticum aestivum L.) differing in resistance against Stagonospora nodorum (Berk.) Cast. and Germ. = Septoria nodorum (Berk.) Berk. J. Phytopathol. 122, 289-306.

Starkey, D.E., Ward, T.J., Aoki, T., Gale, L.R., Kistler, H.C., Geiser, D.M., Suga, H., Tóth, B., Varga, J., O'Donnell, K., 2007. Global molecular surveillance reveals novel Fusarium head blight species and trichothecene toxin diversity. Fungal Genet. Biol. 44, 1191-1204.
Stein, J.M., Osborne, L.E., Bondalapati, K.D., Glover, K.D., Nelson, C.A., 2009. Fusarium head blight severity and deoxynivalenol concentration in wheat in response to Gibberella zeae inoculum concentration. Phytopathology 99, 759-764.

Sutton, J.C., 1982. Epidemiology of wheat head blight and maize ear rot caused by Fusarium graminearum. Can. J. Plant Pathol. 4, 195-209.

Tekle, S., Dill-Macky, R., Skinnes, H., Tronsmo, A.M., Bjørnstad, Å., 2012. Infection process of Fusarium graminearum in oats (Avena sativa L.). Eur. J. Plant Pathol. 132, 431-442.

Trigo, E., Cap, E., Malach, V., Villarreal, F., 2009. The Case of Zero-tillage Technology in Argentina - IFPRI Discussion Paper 00915. Available at: http://www.ifpri.org/ sites/default/files/publications/ifpridp00915.pdf (last accessed 17.07.14.).

Wang, J.-H., Ndoye, M., Zhang, J.-B., Li, H.P., Liao, Y.-C., 2011. Population structure and genetic diversity of the Fusarium graminearum species complex. Toxins 3 , 1020-1037.

Ward, T.J., Bielawski, J.P., Kistler, H.C., Sullivan, E., O'Donnell, K., 2002. Ancestral polymorphism and adaptive evolution in the trichothecene mycotoxin gene cluster of phytopathogenic Fusarium. Proc. Natl. Acad. Sci. U. S. A. 99, 9278-9283. 